\title{
Vena cava inferior leiomyosarcoma kezelése cavotomiával és a jobb vena renalis neoimplantatiójával
}

\author{
Treatment of vena cava inferior leiomyosarcoma with cavotomy \\ and right renal vein neoimplantation
}

\author{
BÁRdos DÁVID, NAGY ZOLTÁN, PEKLI DAMJÁN, FÜLÖP ANDRÁs, SZIJÁRTÓ ATTILA ${ }^{\circledR}$ \\ Semmelweis Egyetem, I. sz. Sebészeti és Intervenciós Gasztroenterológiai Klinika, Budapest \\ (intézetvezető: Prof. Szijártó Attila)
}

\begin{abstract}
A vena cava inferior leiomyosarcomája a vena tunica mediájából kiinduló igen ritka rosszindulatú daganat. Tünetei és radiomorfológiai jelei nem mindig juttatnak pontos kórisméhez, szövettani mintavétele pedig elhelyezkedése miatt veszélyes lehet. Diagnózisa ezért sokszor jelent kihívást a klinikusok számára. Kezelése elsősorban sebészi, amelyet együtt vagy monoterápiában alkalmazott radioterápia és kemoterápia egészít ki.

Esetünkben egy 74 éves nőbeteg tünetmentes, a v. cava inferior jobb v. renalis fölötti részének jobb mellékvesével összefüggő tumorát találtuk. Endokrinológiai kivizsgálása során a szérum kortizol, adrenalin, noradrenalin, adenocorticotrop hormon (ACTH), teljes és szabad tesztoszteron, dehidroepiandroszteron-szulfát (DHEA-S), nemi hormon kötőfehérje (sex hormone binding globulin, SHBG) normál tartományban volt, a tumor hormonszekréciót nem mutatott. A tumor sebészi eltávolítása mellett döntöttünk. Preoperatív biopsziát annak kockázatai miatt nem végeztünk.

A mütét során a v. cava inferior daganatát találtuk, a tumor eltávolítását végeztük a vena falának resectiójával, a jobb mellékvese eltávolításával és a jobb v. renalis neoimplantatiójával. A jobb feltárás érdekében a mütét elején cholecystectómiát is végeztünk. A műtét után szövődmény nem jelentkezett. A beteg adjuváns radioterápiában részesült.

A tumor korai diagnózisának és en bloc resectiójának köszönhetően jelentősen növeltük a beteg gyógyulási esélyeit, az elvégzett radioterápiával pedig csökkentettük a recidíva valószínüségét.
\end{abstract}

Kulcsszavak: vena cava inferior, leiomyosarcoma, általános sebészet, érsebészeti beavatkozások

Leiomyosacroma of the inferior vena cava is an extremely rare malignancy originating from the tunica media of the venous wall. Its symptoms and radiomorphological signs do not always lead to an accurate diagnosis. Histological sampling can be dangerous due to its location. Therefore the diagnosis is often a challenge for clinicians. Its treatment is primarily surgical, supplemented by radiotherapy and chemotherapy applied together or in monotherapy.

In our case, an asymptomatic 74-year-old female patient was diagnosed with a tumor of the inferior caval vein located just above the right renal vein and involving the right adrenal gland. As serum cortisol, epinephrine, norepinephrine, adrenocorticotropic hormone (ACTH), total and free testosterone, dehydroepiandrosterone sulfate (DHEA-S), sex hormone binding globulin (SHBG) was at normal level, the tumor showed no hormone secretion. Primary surgical resection was planned. Preoperative biopsy was not performed due to its high risk of complications.

During operation, tumor resection was performed by resection of the venous wall, removal of the right adrenal gland and neoimplantation of the right renal vein. For better exposure, cholecystectomy was also performed at the beginning of surgery. There were no postoperative complications. The patient received adjuvant radiation therapy.

Thanks to the early diagnosis of the tumor and the complete resection, we significantly increased the patient's chances of total recovery. With the radiotherapy performed, we reduced the likelihood of tumor recurrence.

Keywords: inferior vena cava, leiomyosarcoma, general surgery, vascular surgical procedures

Beérkezett: 2020. október 19.; elfogadva: 2020. november 20.

@Levelezési cím/Corr. address: Prof. Szijártó Attila, Semmelweis Egyetem, I. Sz. Sebészeti és Intervenciós Gasztroenterológiai Klinika, 1085 Budapest, Üllöi út 78. Tel.: +36 1 313-5216/2120, E-mail: igazgato_seb1@med.semmelweis-univ.hu 


\section{Bevezetés}

A vena cava inferior (VCI) leiomyosarcomája (LMS) a vena tunica mediájából kiinduló igen ritka rosszindulatú daganat. Első ízben Perl és Virchow számoltak be róla 1871-ben, ${ }^{1}$ azóta csak kevesebb mint 400 esetet írtak le az irodalomban. Diagnózisa és terápiája kihívást jelent a klinikusok számára, a kis esetszámra való tekintettel nincs erős ajánláson alapuló konszenzus pontos kezelésével kapcsolatban.

$\mathrm{Az}$ esetünkben bemutatott betegnek a tünetmentes, szürő képalkotó vizsgálattal felfedezett vena cava inferior leiomyosarcomájának gyógyításában a primer sebészi kezelést választottuk. A tumort a vena falának kimetszésével, a jobb vena renalis rekonsrukciójával, illetve a jobb mellékvese resectiójával távolítottuk el szövődménymentesen.

\section{Esetbemutatás}

Esetismertetésünkben egy 74 éves nőbetegről számolunk be. Távoli anamnézisében tonsillectomia, myoma uteri miatt végzett enucleatio, varicectomia, strumectomia, rectum polypectomia, hypertonia, a bal alsó végtag trombophlebitise és többszöri thrombosisa, 2-es típusú diabetes mellitus, ischaemiás dilatativ cardiomyopathia, hypothyreosis, dyslipidaemia, valamint uterus prolapsus és cystocele miatti gyürüimplantatio szerepel.

A panaszmentes betegnek a háziorvosa szürő hasi ultrahangvizsgálatot írt elö, amely a jobb mellékvesében egy $3 \mathrm{~cm}$-es inhomogén echoszegény képletet véleményezett.

Tekintettel az elváltozásra komputertomográfia- (computed tomography, CT) vizsgálat történt (1. ábra), amely a bal mellékvesét enyhén nagyobbnak látta, benne körülírt elváltozást nem talált. Jobb oldalon retroperitonealisan a mellékvesét magában foglaló, a jobb v. renalis beömlése fölött a v. cava inferiort komprimáló, annak falát is infiltráló, lumenébe törő, $33 \mathrm{~mm}$ legnagyobb átméröjü, hypodens térfoglalást véleményezett, mely elsősorban mellékvesecarcinomának imponált. A beteget sebészi konzíliumra irányították. Endokrinológiai vizsgálatot és mágnesesrezonancia- (MR) vizsgálatot javasoltunk.

Az MR-vizsgálat (2. ábra) a bal mellékvese solitaer adenomáját és a jobb mellékvese multiplex adenomáját véleményezte. Az ultrahangon és a CT-n is ábrázolódó elváltozást a v. cava inferior falát infiltráló, annak lumenébe törö retroperitonealis daganatként írta le, amely a jobb mellékvesétől elkülönülni látszott. A v. cava inferior keringése mind ultrahanggal, mind CT-vel, mind MR-rel vizsgálva

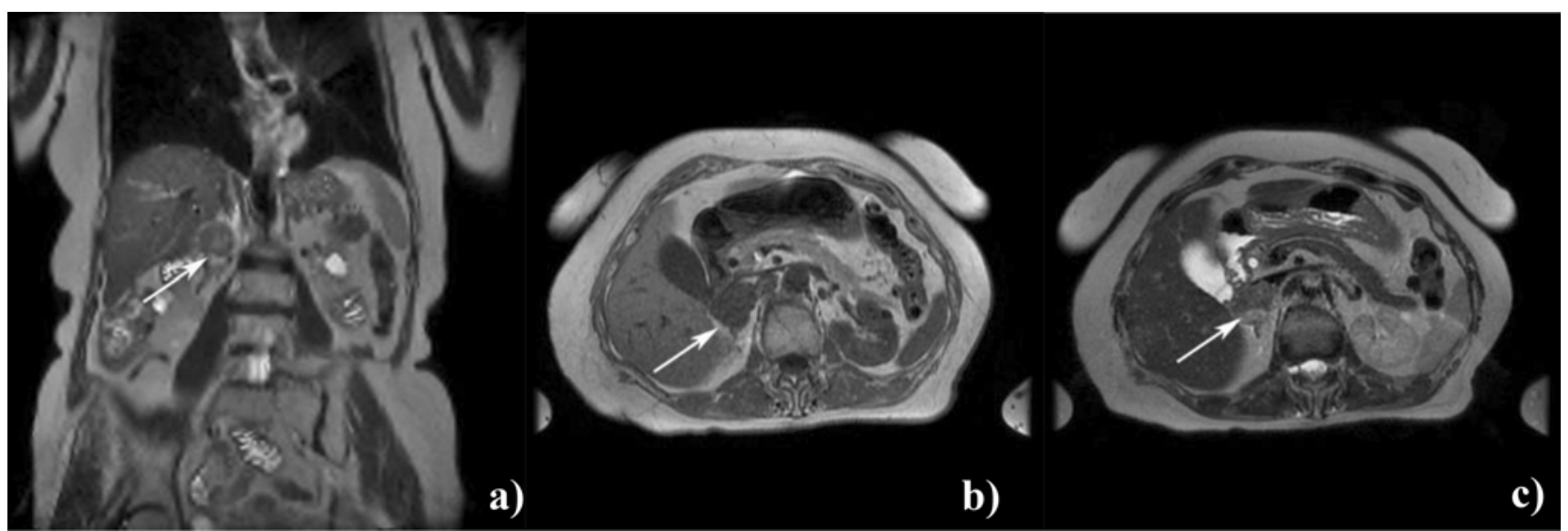

1. ábra. a, b, c. T2-súlyozott coronalis és axialis, valamint dual echo axialis MR-metszetek. A tumor diffúz, alacsony jelintenzitást mutat

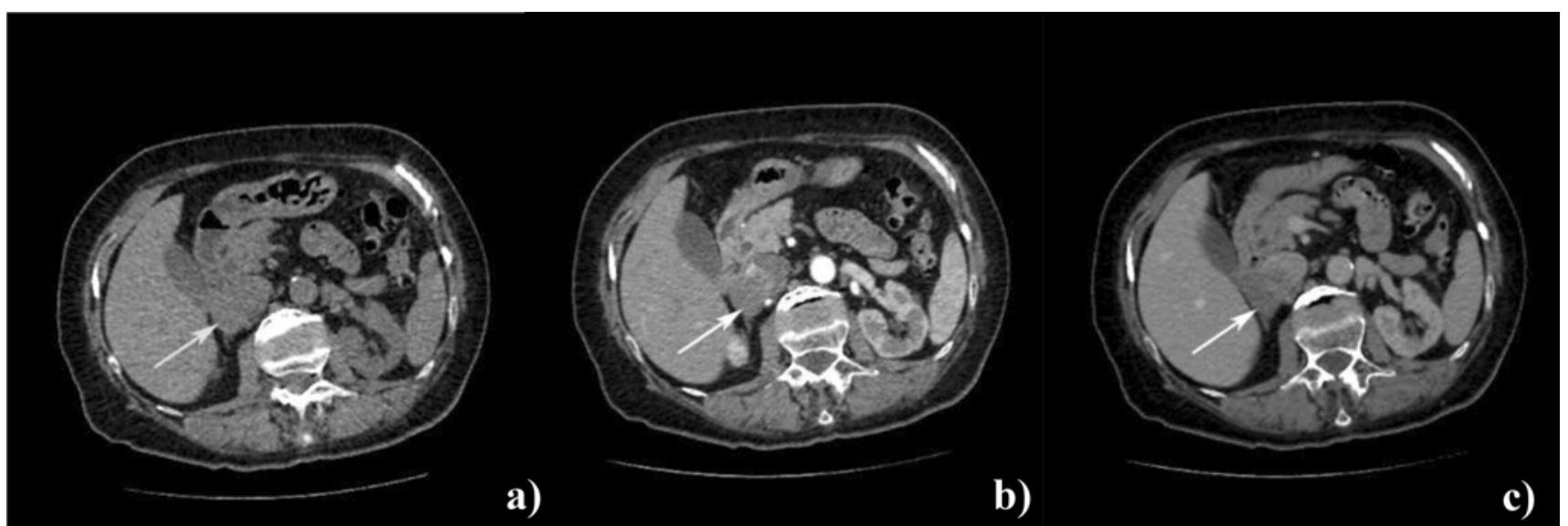

2. ábra. a, b, c. Natív, valamint arteriás és venás fázisú kontrasztanyagos axialis CT-metszetek. A vena cava inferiorban hypodenz, kontrasztanyagot diffúzan halmozó térfoglalás látható 


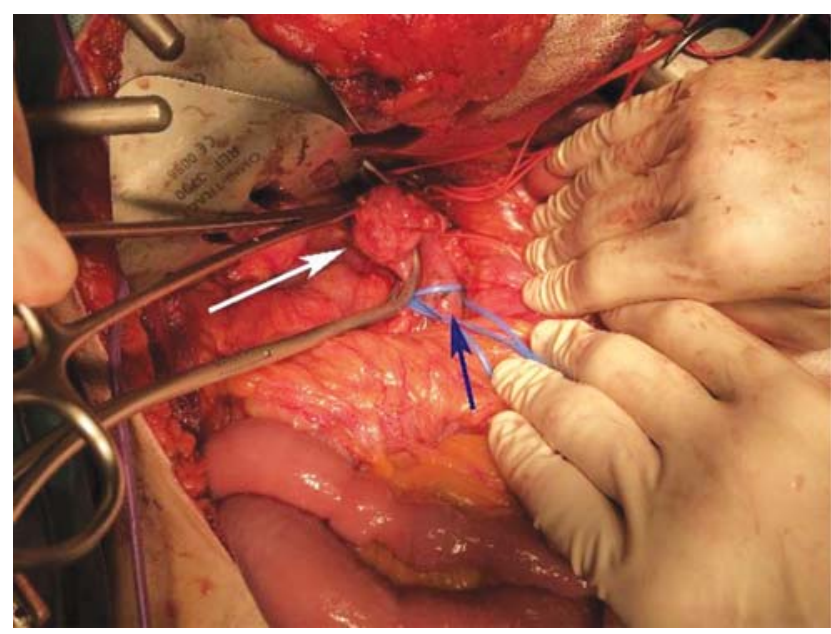

3. ábra. A vena cava inferior (kék nyíl) piros cüglire vett proximalis és kék cüglire vett distalis szakasza, a tumor (fehér nyíl) és a venafal kirekesztett tumoros része

megtartott volt, távoli propagatio egyik képalkotó vizsgálattal sem mutatkozott.

Endokrinológiai kivizsgálása során szérum kortizol, adrenalin, noradrenalin, adenocorticotrop hormon (ACTH), teljes és szabad tesztoszteron, dehidroepiandroszteronszulfát (DHEA-S), nemi hormon kötőfehérje (sex hormone binding globulin, SHBG) normál tartományban voltak. Az elváltozás ez alapján hormon szekrécióját nem mutatta. A pajzsmirigy serkentő hormon (thyroid-stimulating hormone, TSH) szintje levothyroxin mellett normál tartományban volt.

A betegnek az elváltozás kivizsgálása során továbbra sem okozott panaszt.

Tekintettel a malignusnak imponáló, távoli propagatiót nem mutató, a képalkotó vizsgálatok alapján a vena cava inferiorból vagy a retroperitoneumból kiinduló elváltozásra, annak sebészi eltávolítása mellett döntöttünk. A vérzés jelentős kockázatával fenyegető preoperatív biopsiát nem végeztünk.

A mütét során a jobb vese felső pólusán a retroperitoneumban a képalkotók által leírt helyen egy $3 \times 3 \mathrm{~cm}$ átméröjü idegenszövetet találtunk (3. ábra). A tumor a vena cava inferiort közvetlenül a jobb v. renalis beömlése fölött infiltrálta, lumenébe betört, a mellékvesétől azonban elválasztható volt. Cavotomiát végezve a tumort eltávolítottuk (4. ábra). A vena cava falát tovafutó öltéssel zártuk. A resectiót követően a jobb v. renalis pangását észleltük, ezért beömlésénél átvágtuk, és a v. cava inferior neoimplantatióját végeztük (5. ábra). A vena cava és a vena renalis keringése ezt követöen megtartott volt. A mütét kezdetén a biztos feltárás érdekében cholecystectomiát végeztünk.

A posztoperatív időszakban szövődmény nem lépett fel. A beteg jó általános állapotban távozott klinikánkról.

A posztoperatív patológiai vizsgálat makroszkóposan egy $40 \times 35 \times 30$ mm átmérőjü, a mellékvesétől elválasztható, a v. cava falával összefüggő tumort írt le. A szövettani vizsgálat atípiát mutató orsósejtekből álló rosszindu-

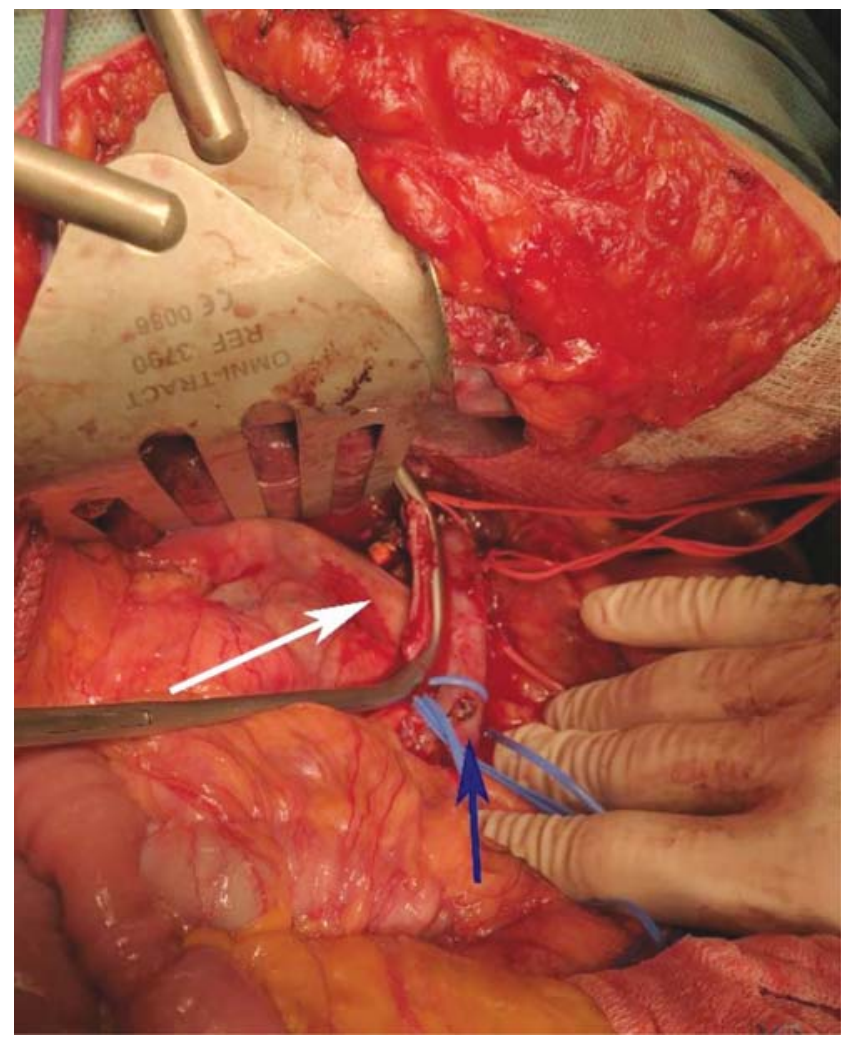

4. ábra. A vena cava inferior (kék nyíl) piros cüglire vett proximalis és kék cüglire vett distalis szakasza, a resecált tumor helye

(fehér nyíl) és a venafal kirekesztett, resecált tumoros része

latú daganat képét látta, a tumor egyes részein alacsonyan differenciált volt. Az osztódó sejtek száma magas, 11 mitosis/10 NNL (nagy nagyítású látótér) volt. Az immunhisztokémiai vizsgálat diffúz erős simaizom-aktin- (smoothmuscle actin, SMA) és H-caldesmon-pozitivitást mutatott. Necrosis nem volt látható. A retroperitoneum felé a daganat elérte a resectiós szélt. Ezek alapján a patológiai vizsgálat a vena cava inferior leimoyosarcomáját bizonyította.

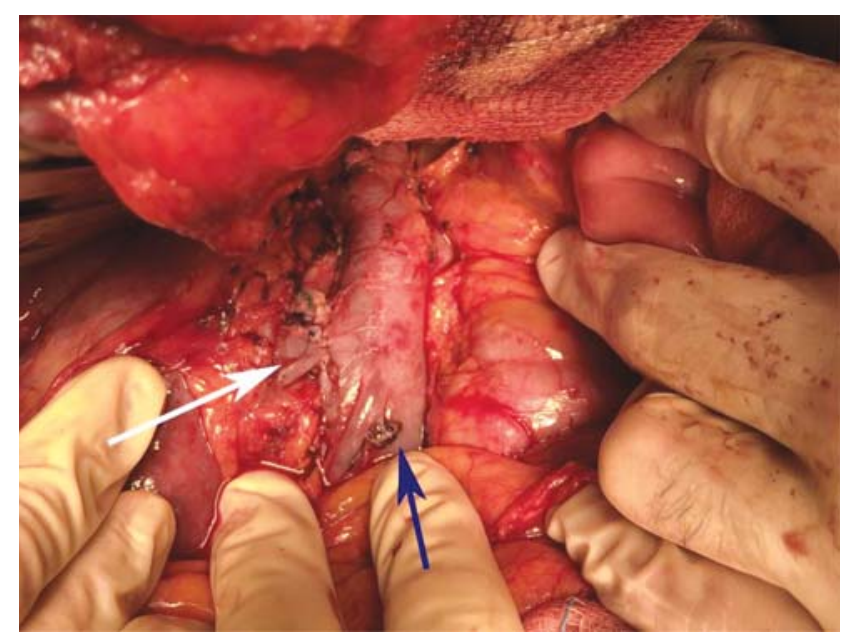

5. ábra. A resecált falú, suturázott v. cava inferior (kék nyíl) a neoimplantált jobb v. renalisszal (fehér nyíl). Az erek keringése megtartott 


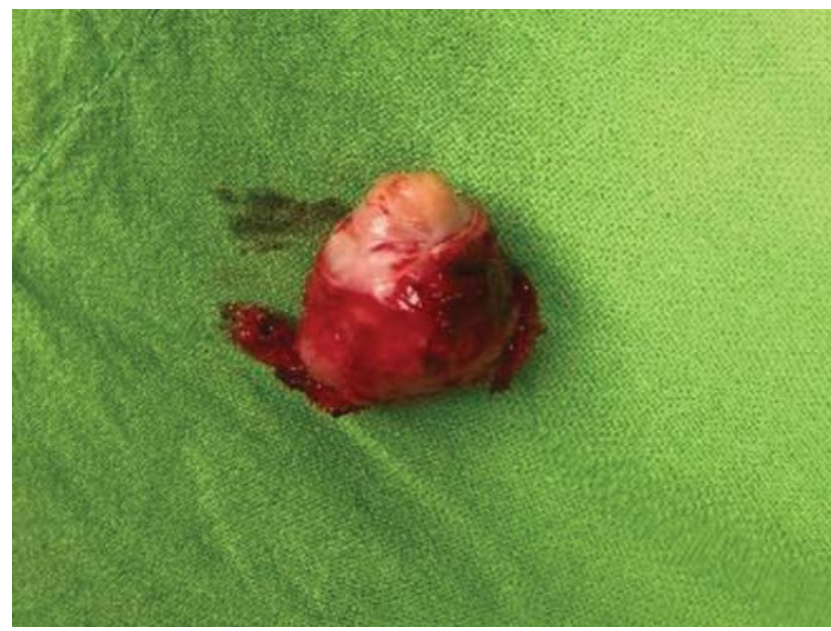

6. ábra. A resecált specimen a tumorral, a vena falával és a jobb mellékvese részleteivel

A beteget posztoperatívan onkoteamnek referáltuk. Adjuváns radioterápiát javasoltak, melyet a beteg a mütét után megkapott.

\section{Megbeszélés}

A vena cava inferior leimyosarcomája extrém ritka daganat. Nőkben 4-szer gyakoribb, mint férfiakban. Átlagosan az ötvenes életévekben jelentkezik. ${ }^{2}$

Típusosan aspecifikus tünetekkel jelentkezik, úgymint a hasi fájdalom (67\%) és a tapintható hasi terime (43\%). Kompressziót okozva alsó végtagi ödémával (35\%) és Budd-Chiari-szindrómával (17\%) járhat. Ritkább esetekben fogyás $(22 \%)$, hasi körfogat-növekedés $(22 \%)$, gyengeség $(12 \%)$, émelygés (12\%), dyspnoe $(11 \%)$, láz $(9 \%)$, étvágytalanság $(9 \%)$, hányás $(9 \%)$, sárgaság (4\%) és éjszakai izzadás (3\%) kísérik. Az esetek egy kisebb részében (4\%) teljesen panaszmentes. ${ }^{3}$

Anatómiai helyzete szerint három típusra oszthatjuk. ${ }^{4}$ Az I. típusba a VCI jobb pitvar és v. hepaticák közötti szakaszából kiinduló daganatok, a II. típusba a v. hepaticák és a v. renalisok beömlése között, a III. típusba pedig a v. renalisok alatt elhelyezkedő daganatok tartoznak. A tumor leggyakrabban az alsó és középső szegmensben helyezkedik el (37\% és 43\%), ritkábban pedig a v. hepaticák fölött (19\%). Az anatómiai elhelyezkedés szerint a középső szegmens tumora mutatja a legjobb prognózist, míg a felső szegmens tumora messze a legrosszabbat. ${ }^{3}$

A növekedés irányát tekintve egyaránt mutathat extraluminalis és intraluminalis növekedést, amelyek közül az előbbi 4-szer nagyobb gyakoriságot mutat. ${ }^{3}$

Biztos diagnózisát a core biopsiás mintavétel jelenti, amely azonban a tumor elhelyezkedésének köszönhetően magas kockázattal jár, bizonyos esetekben pedig kivitelezhetetlen. ${ }^{5}$

Diagnózisában mintavétel hiányában döntő szerepe van a klinikai megjelenés, valamint a különböző képalkotó vizsgálatok együttes elemzésének. A tumort legtöbbször hasi ultrahang- vagy kontrasztanyagos CT-vizsgálattal diagnosztizálják, amely elsősorban a tumor méretének meghatározására és követésére alkalmas, pontos diagnózishoz rendszerint nem juttat. Pontosabb diagnosztikai eszköz az MR, amelynek T1- és T2-súlyozott szekvenciái jobb felbontást biztosítanak a lágyrészek tekintetében. A kontrasztanyagos ultrahangvizsgálat pedig a benignus és malignus elváltozások elkülönítésében jelenthet segítséget. 6,7 Elhelyezkedésének köszönhetően azonban mindezen eljárások mellett is nehezen különíthető el a környező szövetek - a retroperitoneum, mellékvese, vese, máj - térfoglaló elváltozásaitól, valamint a vena cava inferior (tumor) thrombusától. Ennek köszönhetöen gyakran jelent diagnosztikai nehézséget.

Kezelése elsősorban sebészi, amely kihívást jelenthet a környező szervek infiltrációja, illetve a v. cava inferior és az esetleg érintett v. renalisok, v. hepaticák rekonstrukciójának nehézsége miatt. A rekonstrukció történhet primer suturával vagy grafttal. ${ }^{8,9}$

Az onkológiai kezelés kis elemszámú esetriportok alapján a túlélés és a tumor recidíva tekintetében előnyösnek látszik. Az onkológiai eljárások közül a monoterápiában alkalmazott kemoterápia és sugárterápia bizonyult biztonságosnak és feltételezhetően előnyösnek, valamint a kemoterápiával kombinációban alkalmazott sugárterápia vagy deepwave hypertermia. ${ }^{5}$

$\mathrm{Az}$ onkológiai kezelés időzítése ugyancsak kutatás tárgya. Kis esetszámú retrospektív tanulmányok alapján feltételezik a neoadjuváns terápia elönyét, különösen primeren irresecabilis vagy borderline resecabilis tumorok esetén. Randomizált vizsgálatok azonban nem állnak rendelkezésre, a kérdés még vita tárgyát képezi. ${ }^{5}$

A betegség prognózisát elsősorban a tumor resecabilitása határozza meg. Resecabilis esetben az 5 és 10 éves túlélés $49 \%$, illetve 30\%, míg irresecabilis esetben hosszú távú túlélésről nem beszélhetünk, az átlagos túlélés 5 hónap. ${ }^{3}$

Resecabilis esetben is számolni kell azonban lokális recidivával vagy távoli metastasissal, melyek a betegek több mint felében jelentkeznek két éven belül. ${ }^{2,3}$

\section{Következtetés}

A vena cava leiomyosarcoma az érfal tunica mediájából kiinduló ritka daganat. Alacsony számú előfordulásának és anatómiai elhelyezkedésének köszönhetően gyakran jelent differenciáldiagnosztikai kihívást, melyben a kockázatos core biopsia, illetve a klinikai megjelenés és a képalkotó vizsgálatok együttes elemzése nyújthat segítséget.

Kezelése elsősorban sebészi, azonban egyre több adat támasztja alá a kiegészítő onkológiai kezelés fontosságát. Prognózisát elsősorban a tumor resecabilitása határozza meg.

Esetünkben bemutattuk a v. cava inferior középső harmadának incidentalisan felfedezett leiomyosarcomáját, amelyet cavotomiával és a jobb v. renalis neoimplantatiójával, valamint a jobb mellékvese eltávolításával resecál- 
tunk. A tumor korai diagnózisának és en bloc resectiójának köszönhetően jelentősen növeltük a beteg gyógyulási esélyeit, az elvégzett radioterápiával pedig csökkentjük a recidíva valószínüségét.

Munkamegosztás: A szerzők a cikk elkészültében az alábbi módon vettek részt: dr. Szijártó Attila, dr. Nagy Zoltán: operáció; dr. Pekli Damján, dr. Bárdos Dávid: adatok gyüjtése, asszisztencia; dr. Fülöp András: adatok gyüjtése, korrektúra.

\section{Irodalomjegyzék}

${ }^{1}$ Perl L, Virchow R: Ein Fall von Sarkom der Vena cava inferior. Archiv für pathologische Anatomie und Physiologie und für klinische Medicin 1871; 53: 378-383.

${ }^{2}$ Mingoli $A$ et al.: Leiomyosarcoma of the inferior vena cava: analysis and search of world literature on 141 patients and report of three new cases. J Vasc Surg. 1991; 14(5): 688-699.

${ }^{3}$ Mingoli $A$ et al.: International registry of inferior vena cava leiomyosarcoma: analysis of a world series on 218 patients. Anticancer Res. 1996; 16(5B): 3201-3205.
${ }^{4}$ Munene $G$ et al.: Neoadjuvant radiotherapy and reconstruction using autologous vein graft for the treatment of inferior vena cava leiomyosarcoma. J Surg Oncol. 2011; 103(2): 175-178.

${ }^{5}$ Trans-Atlantic RPSWG: Management of primary retroperitoneal sarcoma (RPS) in the adult: a consensus approach from the Trans-Atlantic RPS Working Group. Ann Surg Oncol. 2015; 22(1): 256-263.

${ }^{6}$ Wu $\mathrm{X}$, Zhou P, Li K: Contrast-enhanced ultrasonography of intraluminal inferior vena cava leiomyosarcoma: A case report. J Clin Ultrasound 2020; 48(6): 357-361.

${ }^{7}$ Bednarova, I et al.: Case 257: Leiomyosarcoma of the Inferior Vena Cava. Radiology 2018; 288(3): 901-908.

${ }^{8}$ Biro ZJ et al.: Surgical treatment of primary leiomyosarcoma of the inferior vena cava. Magy Seb. 2009: 62(2): 83-86.

${ }^{9}$ Higutchi $C$ et al.: Vascular reconstruction technique using a tubular graft for leiomyosarcoma of the inferior vena cava: A case report. EJVES Short Rep. 2017; 36: $5-8$.

A cikk a Creative Commons Attribution 4.0 International License (https://creativecommons.org/licenses/by/4.0/) feltételei szerint publikált Open Access közlemény, melynek szellemében a cikk bármilyen médiumban szabadon felhasználható, megosztható és újraközölhetö, feltéve, hogy az eredeti szerző és a közlés helye, illetve a CC License linkje és az esetlegesen végrehajtott módosítások feltüntetésre kerülnek. (SID_1) 